\title{
Korelasi Kadar PlasminogenActivator Inhibitor-1 [PAI-1] Plasma dengan Enzim Transaminase Serum pada Demam Berdarah Dengue
}

\author{
Budi Santosa, ${ }^{*}$ Kisdjamiatun RMD, ${ }^{*}$ Tatty Ermin, ${ }^{*}$ Ni Putu Aniek Mahayani* \\ *Bagian IKA FK UNDIP RSUP Dr. Kariadi Semarang \\ **Bagian Parasitologi FK UNDIP RSUP Dr. Kariadi Semarang
}

\begin{abstract}
Latar belakang. Plasminogen activator inhibitor-1 (PAI-1) adalah inhibitor fibrinolisis yang berperan pada patogenesis demam berdarah dengue (DBD). Peningkatan PAI-1 akan menyebabkan peningkatan status prokoagulasi yang menyebabkan terbentuknya mikrotrombi dan menyebabkan gagal multi organ dan kematian. Serum SGOT dan SGPT digunakan sebagai penanda kerusakan hepatoselular. Peningkatan kadar kedua penanda ini dapat menjadi indikator keparahan penyakit DBD.

Tujuan. Mengetahui korelasi antara PAI-1 plasma terhadap SGOT dan SGPT serum

Metode. Penelitian observasional analitik dengan cross sectional time series. Subjek adalah pasien DBD yang dirawat di bangsal anak RSUP Dr. Karyadi selama bulan Juli 2005 -Juli 2006, berusia 3-14 tahun yang bersedia berpartisipasi secara tertulis. Dilakukan pemeriksaan kadar PAI-1 dan SGOT, SGPT pada hari ke 0 dan 2, di Lab Patologi Klinik RSDK menggunakan alat Dade Behring seri Dimension RXL. Dilakukan uji korelasi Spearman untuk mengetahui hubungan PAI-1 dengan SGOT dan SGPT

Hasil. Jumlah subjek penelitian 49 orang. Sebagian besar berjenis kelamin perempuan dengan rerata umur $(7,3 \pm 2,7)$ tahun, rerata kadar PAI-1 hari $0(98,8 \pm 142,60 \mathrm{ng} / \mathrm{ml})$ lebih tinggi daripada hari ke $2(55,1 \pm 29,59$ $\mathrm{ng} / \mathrm{ml}) ; \mathrm{p}=0,001$. Kadar SGOT hari ke $0(173,3 \pm 159,11) \mathrm{U} / \mathrm{L}$ lebih tinggi daripada hari ke $2(132,3 \pm$ $110,78) \mathrm{U} / \mathrm{L} \mathrm{p}<0$, sedangkan serum SGPT hari ke $2(72,4 \pm 68,92 \mathrm{U} / \mathrm{L})$ lebih tinggi daripada hari ke 0 $(65,1 \pm 49,35 \mathrm{U} / \mathrm{L}) \mathrm{p}=0,8$.Uji korelasi kadar PAI-1 dengan serum SGOT dan SGPT hari ke $0(\mathrm{r}=0,33, \mathrm{p}=0,02)$ dan $(0,49 \mathrm{p}<0,001)$; hari ke $2(\mathrm{r}=0,30 \mathrm{p}=0,03)$ dan $(\mathrm{r}=0,35, \mathrm{p}=0,01)$

Kesimpulan. Terdapat korelasi positif derajat lemah antara kadar PAI-1 plasma dengan kadar SGOT dan SGPT serum pada pemeriksaan hari ke-0 dan ke-2. (Sari Pediatri 2010;12(1):6-10).
\end{abstract}

Kata kunci: PAI-1, SGOT, SGPT, demam berdarah dengue

\footnotetext{
Alamat korespondensi:

Dr. Budi Santosa. Bagian Ilmu Kesehatan Anak Fakultas Kedokteran Universitas Diponegoro / RS Dr. Kariadi. Jl. Dr. Sutomo 16 Semarang. Telp. / Fax. +6224-8414296, 8311471 ex 376

E-mail: e-tatty@ melsa.net.id,

Dr. Ni Putu Aniek Mahayani, E-mail: putuaniek@yahoo.co.id
}

I nfeksi dengue merupakan penyakit yang sangat penting pada manusia. Diperkirakan 50-100 juta penduduk dunia terinfeksi virus dengue. Kasus demam berdarah dengue di seluruh 
dunia diperkirakan setiap tahunnya berjumlah 250.000-500.000. ${ }^{1,2}$ Angka kematian DBD di Indonesia secara umum $1,2 \%$ pada tahun $2004,{ }^{3}$ sedangkan untuk Sindrom Syok Dengue (SSD) angka kematiannya masih tinggi. Pada tahun 2002, angka kematian DBD berat (syok berkepanjangan, syok berulang dan perdarahan masif) yang dirawat di Pediatric Intensive care unit (PICU) RSUP Dr. Kariadi masih tinggi yaitu $12 \%$ pada tahun 2002 dan dengan kualitas pemantauan yang meningkat, deteksi syok secara dini, peningkatan kualitas pengelolaan cairan, angka kematian DBD menjadi menurun menjadi $10,8 \%$ pada tahun $2004 .^{3}$ Gangguan hemostasis yang terjadi pada infeksi dengue mempunyai karakteristik tertentu, dengan manifestasi klinis beragam mulai dari petekie pada kulit sampai pada perdarahan yang berat seperti hematemesis dan melena. Banyak penelitian telah dilakukan untuk menerangkan gangguan fungsi trombosit, koagulopati serta vaskulopati yang terjadi pada tingkatan yang bervariasi. Pada fase awal demam, perdarahan yang terjadi disebabkan oleh vaskulopati dan trombositopenia dan pada fase syok disebabkan oleh trombositopenia dan koagulopati terutama pembekuan intravaskular menyeluruh dan peningkatan fibrinolisis. Pada penelitian lain dikatakan bahwa defek pada fungsi vaskular dan gangguan hemostasis dapat terjadi pada setiap derajat DBD yang dapat mengakibatkan terjadinya perubahan pada sel endotel yang kehilangan fungsi proteksi non trombotik menjadi status prokoagulan yang bisa menyebabkan terbentuknya trombus. ${ }^{4}$ Adanya disfungsi endotel ditunjukkan dengan meningkatnya kadar plasminogen activator inhibitor (PAI-1) sirkulasi dan merupakan petanda dini dari disfungsi endotel. ${ }^{5}$ Pada beberapa penelitian di luar infeksi dengue seperti pada penyakit fibrosis hati, steatohepatitis, dan non alkoholik penyakit hati, yang merupakan penyakit primer pada hati, menunjukkan bahwa PAI-1 berperan dalam patogenesis penyakit dan ada hubungan antara kadarnya dengan derajat keparahan penyakit-penyakit tersebut ${ }^{6,7,8}$ Bagaimana hubungan kadar PAI-1 dengan peningkatan kadar SGOT dan SGPT pada infeksi virus dengue belum pernah diteliti. Penelitian ini bertujuan untuk mengetahui hubungan antara kadar PAI-1 dengan kadar SGOT dan SGPT pada pasien dengan infeksi virus dengue yang menunjukkan keterlibatan hati pada penyakit ini.

\section{Metode}

Desain penelitian adalah cross sectional time series. Sampel adalah semua pasien DBD berumur 3-14 tahun yang dirawat di Bagian Ilmu Kesehatan Anak RS. Dr. Kariadi Semarang selama periode penelitian (Juli 2005-Juli 2006) yang memenuhi kriteria inklusi, diagnosis DBD berdasarkan kriteria WHO 1999 yang dikonfirmasi dengan pemeriksaan serologis, tidak menderita gizi buruk, bersedia ikut dalam penelitian, Kriteria eksklusi, mengalami sepsis, tidak mengikuti sampai selesai atau pemeriksaan darah tidak lengkap. Sampel diambil pada hari ke 0 (hari pada saat diagnosis DBD ditegakkan) dan hari ke-2. Pemeriksaan PAI-1 dilakukan di Laboratorium Cebior RSDK sedangkan SGOT dan SGPT diperiksa di Laboratorium Patologi Klinik RSDK menggunakan alat Dade Behring seri Dimension RXL

Data dilakukan analisis univariat. Normalitas data PAI-1 dan SGOT dan SGPT serum diuji dengan uji Kolmogorov-Smirnov. Untuk mengetahui korelasi antara kadar PAI-1 dan SGOT dan SGPT serum menggunakan analisis bivariat. Uji korelasi Spearman digunakan karena data berdistribusi tidak normal. Nilai p dianggap bermakna apabila $\mathrm{p}<0,05$. Rentang interval kepercayaan yang digunakan adalah $95 \%$ interval kepercayaan.

\section{Hasil}

Pada periode penelitian dijumpai 83 pasien suspek DBD yang dirawat di RS. Dr. Kariadi Semarang. Berdasarkan kelengkapan data hanya 49 subjek yang digunakan untuk analisis data. Karakteristik subjek penelitian tertera pada Tabel 1 .

Tabel 1 menunjukkan rerata umur subjek penelitian adalah 7,3 tahun dengan umur termuda subjek penelitian adalah 1 tahun dan tertua adalah 13 tahun. Jenis kelamin subjek penelitian sebagian besar adalah perempuan $(61,2 \%)$ sedangkan laki-laki $38,8 \%$. Rerata hari demam sebelum dirawat adalah 4,1 hari dengan onset demam tersingkat adalah 1 hari dan terlama adalah 10 hari. Rerata lama perawatan adalah 5,2 hari dengan masa perawatan terpanjang adalah 23 hari. Berdasarkan status gizi diketahui sebagian besar kasus termasuk dalam kategori gizi baik $(55,1 \%)$.

Tabel 2 menunjukkan bahwa pada hari ke-0 perawatan dijumpai kadar SGOT dan SGPT lebih 
Tabel 1. Karakteristik subjek penelitian

\begin{tabular}{lcc}
\hline Karakteristik subjek & Rerata \pm SB & $\mathrm{n}(\%)$ \\
\hline Umur (tahun) & $7,3 \pm 2,70$ & - \\
Jenis kelamin & - & - \\
$\quad$ - Laki-laki & - & $19(38,8)$ \\
- Perempuan & - & $30(61,2)$ \\
Onset demam (hari) & $4,1 \pm 1,57$ & - \\
Lama perawatan (hari) & $5,2 \pm 4,41$ & - \\
Status gizi & - & - \\
- Gizi kurang & - & $19(38,8)$ \\
- Gizi baik & - & $27(55,1)$ \\
- Overweight & - & $3(6,1)$ \\
\hline
\end{tabular}

$\mathrm{SB}=$ simpang baku

tinggi dari normal. Selanjutnya pada hari ke-2 perawatan terjadi penurunan yang bermakna pada SGOT, walaupun demikian kadarnya masih diatas nilai normal. Dilain pihak pada hari ke-2 SGPT justru meningkat, akan tetapi peningkatan tersebut tidak bermakna.

\section{Korelasi antara kadar PAI-1, SGOT, dan SGPT}

Korelasi antara kadar PAI-1, SGOT dan SGPT pada hari ke-0 dan ke-2 tertera pada Tabel 3.

Tabel 3 menunjukkan bahwa pada ada korelasi positif antara kadar PAI-1 dengan kadar SGOT pada hari ke-0 ( $r=0,33 ; p=0,02)$ dan hari ke $2(r=0,49$; $\mathrm{p}<0,001)$ dan SGPT pada hari ke $0(\mathrm{r}=0,30 ; \mathrm{p}=0,03)$ dan hari ke $2(r=0,35 ; p=0,01)$. Subjek penelitian dengan kadar PAI-1 yang tinggi akan memiliki kadar SGOT dan SGPT yang tinggi pula dan sebaliknya atau dapat dinyatakan juga peningkatan kadar PAI-1 akan disertai dengan peningkatan kadar SGOT dan SGPT.

\section{Pembahasan}

Pada penelitian ini dijumpai adanya PAI-1 yang lebih tinggi bermakna pada hari ke-0 dibandingkan hari ke-2. Hasil penelitian kami sesuai dengan penelitian sebelumnya yang menjumpai adanya peningkatan PAI-1 pada anak dengan DBD. Hasil penelitian Wills ${ }^{9}$ pada anak dengan DBD di Vietnam juga mendapatkan penurunan PAI-1 pada hari ke-2 perawatan, walaupun masih di atas nilai normal dan terus menurun kadarnya mencapai nilai normal pada satu bulan setelah keluar rumah sakit. Penelitian Sosothikul ${ }^{10}$ juga mendapatkan peningkatan PAI-1 pada fase febris dan menurun pada fase toksik.

Inhibitor fibrinolisis PAI-1 dihasilkan oleh sel endotel, hepatosit, dan trombosit. Infeksi virus dengue akan mengaktifkan sistem koagulasi monosit dan sel limfosit $\mathrm{T}$ akan mengeluarkan mediator inflamasi seperti IL 1 dan TNF alfa yang akan merangsang produksi dari PAI-1. Dengan menghambat aktivitas fibrinolitik peningkatan PAI-1 akan menyebabkan status

Tabel 2. Perbedaan kadar PAI-1, SGOT dan SGPT serum subjek penelitian hari ke-0 dan ke-2

\begin{tabular}{|c|c|c|c|c|}
\hline \multirow[b]{2}{*}{ Variabel } & \multicolumn{2}{|c|}{ Hari ke- } & \multirow[b]{2}{*}{$\Delta^{\S}$} & \multirow{2}{*}{$\mathrm{p}^{*}$} \\
\hline & $\begin{array}{c}0 \\
\text { Median (IQR) }\end{array}$ & $\begin{array}{c}2 \\
\text { Median (IQR) }\end{array}$ & & \\
\hline PAI-1 (ng/mL) & $74,1(50,35)$ & $53,0(47,56)$ & $-10,66(47,25)$ & 0,001 \\
\hline SGOT (U/L) & $132,0(113,0)$ & $99,0(72,0)$ & $-17,00(71,50)$ & $<0,001$ \\
\hline SGPT (U/L) & $51,0(48,0)$ & $52,0(43,0)$ & $1,00(24,50)$ & 0,8 \\
\hline
\end{tabular}

${ }^{\S}$ Kadar hari ke 2-hari - ke-1

*Uji Wilcoxon

$\mathrm{IQR}=$ Interquartile Range

Tabel 3. Korelasi antara kadar PAI-1 dengan SGOT dan SGPT

\begin{tabular}{lll}
\hline Variabel & $\begin{array}{l}\text { Hari ke-0 } \\
\text { Koefisien korelasi* }\end{array}$ & $\begin{array}{l}\text { Hari ke-2 } \\
\text { Koefisien korelasi* }\end{array}$ \\
\hline PAI-1 dengan SGOT & $0,33(\mathrm{p}=0,02)$ & $0,49(\mathrm{p}<0,001)$ \\
PAI-1 dengan SGPT & $0,30(\mathrm{p}=0,03)$ & $0,35(\mathrm{p}=0,01)$ \\
\hline
\end{tabular}

$\mathrm{r}=$ Koefisien korelasi Spearman

$\mathrm{p}=$ bermakna bila $<0,05$ 
prokoagulasi terjadi deposit fibrin dan menyebabkan terbentuknya trombus. ${ }^{4}$

Penelitian sebelumnya oleh Huang ${ }^{11}$ mendapatkan peningkatan kadar PAI-1 sampai dengan periode penyembuhan (14-27 hari onset demam). Perbedaan ini diduga akibat peningkatan jumlah trombosit sampai masa penyembuhan. Pada penelitian ini pemeriksaan kadar PAI-1 dilakukan pada fase akut atau toksik, pada saat itu terjadi depresi sumsum tulang akibat infeksi virus dengue yang menyebabkan penurunan jumlah trombosit. Penurunan jumlah trombosit diduga menyebabkan penurunan jumlah PAI.

Pada infeksi virus dengue dapat terjadi kerusakan jaringan hati, sebagaimana yang terjadi pada infeksi virus hepatitis. Adanya kerusakan jaringan hati ditandai dengan peningkatan kadar SGOT, SGPT, dan alkali fosfatase. Hal tersebut terjadi pada kasus dengan ataupun tanpa hepatomegali.

Kadar SGOT dan SGPT tinggi pada pangamatan hari ke-0, kadar SGOT lebih tinggi daripada kadar SGPT dan didapatkan kadar SGOT yang rendah bermakna pada pengamatan hari ke-2. Hasil sejalan dengan penelitian sebelumnya yang juga melaporkan adanya peningkatan kadar transaminase dan alkali fosfatase pada anak dengan DBD. Dilaporkan peningkatan terjadi pada awal perawatan di rumah sakit dan turun menjadi normal pada minggu ke-2 sampai minggu ke-3. ${ }^{12}$ Dijumpai peningkatan SGOT lebih besar daripada SGPT, sesuai dengan penelitian Seneviratne $^{12}$ dan Malavige ${ }^{13}$ yang juga melaporkan adanya peningkatan SGOT yang lebih tinggi dibandingkan SGPT pada infeksi dengue, penurunan SGOT lebih cepat daripada SGPT dan mencapai nilai normal kembali dalam dua minggu. Dijumpai peningkatan SGOT yang lebih tinggi dibanding SGPT karena selain oleh hati SGOT juga dilepaskan oleh sel otot skletal dan miokardium yang juga menjadi organ target infeksi dengue. Sedangkan SGPT juga dijumpai di beberapa jaringan, akan tetapi lebih banyak dijumpai di jaringan hati, sehingga SGPT lebih khas untuk jaringan hati daripada SGOT. ${ }^{13}$ Secara klinis kedua enzim tersebut selalu digunakan sebagai penanda adanya kerusakan jaringan hati. Peningkatan moderat (tiga sampai duapuluh kali nilai normal) SGOT dan SGPT menunjukkan adanya peradangan jaringan hati yang bersifat akut. ${ }^{14}$

Hepatomegali hanya dijumpai pada $49 \%$ kasus, sama dengan laporan dari Malaysia yaitu 48\% kasus DBD dijumpai hepatomegali, akan tetapi lebih rendah dibanding di India yang mencapai $74 \%$ dan Thailand 90\%. Penelitian lain di Malaysia melaporkan hepatomegali dijumpai pada $60 \%$ kasus. Hati merupakan salah satu target infeksi dengue, beberapa kondisi patologis seperti nekrosis sentrilobularis, perubahan lemak, hiperplasia sel Kupffer, acidophilic bodies dan infiltrasi monosit traktus portal dilaporkan pada kasus DBD syok. ${ }^{15}$ Keterlibatan jaringan hati dalam infeksi dengue adalah sel hati dan sel Kupffer merupakan tempat replikasi virus dengue. Hasil penelitian sebelumnya melaporkan bahwa semua serotipe virus dengue bereplikasi di hati, walaupun demikian serotipe DEN-3 atau DEN-4 lebih banyak menyebabkan kerusakan jaringan hati dibanding serotipe lainnya.

Didapatkan korelasi positif derajat rendah antara kadar PAI-1 dengan kadar SGOT dan SGPT pada pengamatan hari ke-0 dan ke-2. Penelitian Lagoa $\mathrm{dkk}^{16}$ menunjukkan terjadi peningkatan PAI -1 pada tikus terjadi kerusakan hepar setelah terjadinya syok. Kerusakan yang terjadi dihubungkan dengan mikrotrombi dan iskemia pada sel hepar yang dievaluasi secara mikroskopik.

Selain mengaktivasi endotel virus dengue juga menyebabkan kerusakan pada hati secara langsung melalui replikasi virus dan secara tidak langsung melalui aktivasi makrofag yang selanjutnya menyebabkan peningkatan sel $\mathrm{T} \mathrm{CD}^{+}$dan peningkatan produksi radikal bebas seperti oksigen reaktif dan peroksinitrit radikal bebas tersebut akan menginduksi apoptosis jaringan termasuk jaringan hati. ${ }^{17}$

Keterangan tersebut dapat menjelaskan adanya korelasi positif antara PAI-1 dengan SGOT dan SGPT. Pada infeksi virus dengue selain menginvasi makrofag yang menyebabkan kerusakan endotel yang akan menyebabkan peningkatan PAI-1, virus dengue secara langsung bereplikasi pada sel hati sehingga menyebabkan kerusakan sel hati. Hal tersebut menjelaskan bahwa peningkatan SGOT dan SGPT mencerminkan kerusakan sel hati pada infeksi virus dengue, tidak hanya disebabkan oleh adanya mikrotrombi yang diakibatkan oleh peningkatan PAI-1 tapi juga karena kerusakan sel hati yang disebabkan oleh efek langsung dari virus dengue sendiri pada sel hati.

Keterbatasan penelitian adalah tidak dilakukannya pemeriksaan kerusakan jaringan hati sehingga tidak diketahui secara pasti adanya kerusakan hati. Juga belum diperiksa pengaruh faktor lain seperti viral load, viral strain kadar tF. Pada penelitian ini kami tidak 
membedakan antara pasien DBD dan DSS sehingga belum dapat dibedakan kerusakan hati pada DBD atau DSS.

\section{Kesimpulan}

Terdapat korelasi positif derajat lemah antara kadar PAI-1 plasma dengan kadar SGOT dan SGPT serum pada pemeriksaan hari ke-0 dan ke-2. Perlu dilakukan penelitian lanjutan tentang korelasi PAI-1 dengan SGOT dan SGPT dengan membedakan pasien syok dan non-syok serta faktor-faktor lain yang mempengaruhi kadar SGOT dan SGPT seperti viral load, viral strain dan kadar faktor jaringan.

\section{Daftar Pustaka}

1. Guzman MG, Kouri G. Dengue: An up date. Lancet Infect Dis 2002;2:33-42.

2. Perez JGR, Clark GG, Gubler DJ, Sanders EJ, Vondam AV.Dengue and Dengue Hemorrhagic Fever. Lancet 1998;325:971-7.

3. Setiati TE. Faktor hemostasis dan factor kebocoran vaskuler sebagai factor diskriminan untuk memprediksi syok pada demam berdarah dengue. Disertasi doktor. Bagian Ilmu Kesehatan Anak, FK UNDIP Semarang 2004.

4. ATA Mairuhu, Setiati TE, Koraka P, Hack CE, Leyte A, Faradz SMH, Cate. Increased PAI-1 plasma levels and risk of death from dengue: no association with the 4G/5G promotor polimorphism. Thrombosis J 2005; 3:17.

5. Broadsky SV, Malinowsky K, Golightly M, Yesti J, Goligorsky MS. PAI-1 promotes formation of endothelial microparticles with procoagulant potential.Circulation 2002;106;2372-8.

6. Battaler R, Brenner DA. Hepatic stellate cells as target for treatment of liver fibrosis.. Didapat dari URL : www. medscape.com/ viewarticle/410858. Pada tanggal 10 November 2009.
7. Alessi MC, Bastelica D, Mavri A, Morange P, Berthet B, Grino M, dkk. Plasma PAI-1 liver are more strongly related to liver steatosis than to adipose tissue accumulation. Arterioscler Thromb Vasc Biol 2003;23:1262-8.

8. Thui S, Ladurner R, Volynets V, wagner S, Strachl S, Konigsrainer A, dkk. Nonalcoholic fatty liver disease in human is asscociated with increased plasma endotoxin and plasma activator inhibitor1, concentration and with fructose intake. Am Soc for Nutr 2008;1452-5.

9. Wills BA, Oragui EE, Stephens AC, Daramola OA, Minh Dung N, Thi Loan H, dkk Coagulation abnormalities in dengue hemorrhagic fever: serial investigations in 167 Viatnamese children with dengue shock syndrome. Clin Infect Dis 2002;35:277-85.

10. Sosothikul D, Seksarn P, Pongsewalak S, Thishyakorn U, Lusher J. Activation on endothelial cells, coagulation and fibrinolysis in virus dengue infection. Thromb Haemost 2007;97:627-34.

11. Huang YH, Liu CC, Wang ST, Ley YH, Liu HL, Lin YS, dkk. Activation of coagulation and fibrinolisis during dengue virus infection. J Med Virol. 2001;63;:247-5.

12. Seneviratne SL, Malavige GN dan de Silva HJ. Pathogenesis of liver involvement during dengue viral infections. Roy Soc Trop Med Hyg 2006;100:608-14.

13. Malavige GN, Ranatunga PK, Jayaratne SD, Wijesiriwardana B, Seneviratne SL, Karunatilaka DH. Dengue viral infection as a cause of encephalopathy. India J Med Microb 2007;25;143-5.

14. Tai DI, Chang-Chien CS, Lan CK, Chiou SS, Liaw YF. Liver biochemical tests and dengue fever. Am J Trop Med Hyg 1992;47:265-70.

15. Kalayanarooj S, Nimmannitya S. Is dengue severity related to nutritional status ? J South As J Trop Med Public Health. 2005 ;36:378-84.

16. Lagoa CE, Vodovots Y, Stolz DB, Lhuillier F, McCloskey C, Gallo D, dkk. The role of hepatic type-1 plasminogen activator inhibitor (PAI-1) during murine hemorrhagic shock. Hepatology 2005;42:390-9.

17. Chaturvedi UC, ShrivSGOTava R. Macrophage \& dengue virus: Friend or foe? Indian J Med Res 2006;124:23-40. 